\title{
Habenaria diphylla (Nimmo) Dalzell (Orchidaceae), new record for the flora of Vietnam
}

\author{
Hong Thien Van ${ }^{1 *}$, Thi Hong Van Nguyen ${ }^{1}$, Hong Thia Le ${ }^{2}$, Ngoc Nam Trinh ${ }^{3}$, Nguyen Tuong An \\ Huynh $^{4}$, Van Son Le ${ }^{5}$, Thi Thanh Nha Phan ${ }^{6,7}$ \& Le Anh Tuan Dang, \\ ${ }^{1}$ Institute of Biotechnology and Food Technology, Industrial University of Ho Chi Minh City, No. 12 Nguyen Van Bao Street, Ward 4, Go Vap \\ District, Ho Chi Minh City, Vietnam \\ ${ }^{2}$ Institute of Environmental Science, Engineering and Management, Industrial University of Ho Chi Minh City, No. 12 Nguyen Van Bao Street, \\ Go Vap District, Ho Chi Minh City, Vietnam \\ ${ }^{3}$ Office of Science Management and International Affairs, Industrial University of Ho Chi Minh City, No. 12 Nguyen Van Bao Street, Go Vap \\ District, Ho Chi Minh City, Vietnam \\ ${ }^{4}$ Office of Postgraduate Management, Industrial University of Ho Chi Minh City, No. 12 Nguyen Van Bao Street, Go Vap District, Ho Chi Minh \\ City, Vietnam \\ ${ }^{5}$ Binh Chau-Phuoc Buu Nature Reserve, Bung Rieng Ward, Xuyen Moc District, Ba Ria-Vung Tau Province, Vietnam \\ ${ }^{6}$ Department of Ecology and Evolutionary Biology, University of Science, Vietnam National University HCMC, 227 Nguyen Van Cu Street, \\ District 5, Ho Chi Minh City, Vietnam \\ ${ }^{7}$ Vietnam National University Ho Chi Minh City, Linh Trung Ward, Thu Duc City, Ho Chi Minh City, Vietnam \\ *Email: vanhongthien@iuh.edu.vn
}

\section{ARTICLE HISTORY}

Received: 02 November 2020

Accepted: 16 January 2021

Published: 07 February 2021

\section{KEYWORDS}

Orchidaceae; Habenaria diphylla; Southern Vietnam.

\section{ABSTRACT}

Habenaria diphylla (Nimmo) Dalzell is reported for the first time as a new discovery for the flora of Vietnam based on the specimens collected in Binh Chau-Phuoc Buu Nature Reserve, Ba Ria-Vung Tau Province. The present study provided the detailed characteristics of the species including detailed photographs of the morphological characteristics, the cross section of the leaf, inflorescence axis and root. Furthermore, the information about the species, including distribution, habitat, ecology and conservation status were also provided.

\section{Introduction}

Habenaria Willd, one of the large genus of the family Orchidaceae, has about 876 species which are growing in tropical and subtropical climate (1). In Vietnam, the genus included 30 species (2-4). In another study, there recorded 35 species of this genus in Vietnam, "The Orchids of Vietnam illustrated survey" (5). Recently, $H$. austrosinensis was recorded as new to the flora of Vietnam (6). Therefore, prior to this paper, the total number of known species of Habenaria in Vietnam were 36. Habenaria diphylla (Nimmo) Dalzell was discovered for the first time in India (7). To date, this species found in several countries including Nepal, Bhutan, Bangladesh, China, Myanmar, Thailand, Philippines and India (8-10).

In 2019, we found a population of unusual Habenaria in the field trip at Binh Chau-Phuoc Buu
Nature Reserve, Southern Vietnam. Our careful examination of its morphological attributes indicated that the collected species is $H$. diphylla which represents a new discovery for the flora of Vietnam.

\section{Materials and Methods \\ Materials collection}

Habenaria diphylla specimens were collected from Binh Chau-Phuoc Buu Nature Reserve, Bung Rieng Ward, Xuyen Moc District, Ba Ria-Vung Tau Province, Vietnam on 30 August 2019. All vouchered specimens are encoded as collected Le VS 221, Le VS 222 and deposited at Herbarium of Department of Ecology and Evolutionary Biology, Faculty of Biology and Biotechnology, University of Science, National University Ho Chi Minh City, Vietnam (PHH).

(C) Van et al (2021). This is an open-access article distributed under the terms of the Creative Commons Attribution License, which permits unrestricted use, distribution and reproduction in any medium, provided the original author and source are credited (https://creativecommons.org/licenses/by/4.0/).

To cite this article: Van H T, Nguyen T H V, Le HT, Trinh N N, Huynh N T A, Le V S, Phan T T N, Dang L A T. Habenaria diphylla (Nimmo) Dalzell (Orchidaceae), new record for the flora of Vietnam. Plant Science Today. 2021;8(1):185-189. https://doi.org/10.14719/pst.2021.8.1.1014 


\section{Morphological features}

The guidebook of Royal Botanic Gardens, Kew was used to collect and analyze the specimens (11). By comparing the previously published illustration of Harbenaria specimens, identified the collected specimen $(2,3,5,8-10)$ examining its morphological characteristics.

\section{Taxonomic treatment}

Habenaria diphylla (Nimmo) Dalzell, Hooker's J. Bot. Kew Gard. Misc. 2: 262. 1850. Habenaria humistrata Rolfe ex Downie, Bull. Misc. Inform. Kew 1925: 419. 1925 (Fig. 1, 2 \& 3).

Terrestrial herbs, stem 15-30 cm high. Tuber underground, ellipsoid to subcylindrical, 1-1.2 cm long, 5-8 $\mathrm{mm}$ in diameter, producing some roots. Stem erect, slender, $15-30 \mathrm{~cm}$ high, $12 \mathrm{~mm}$ in diameter, green to pale green, producing few roots at the base. Leaves 2, opposite, appressed to the ground; leaf blade dark green above, pale green below, orbicular to ovate, 4-6 cm long, 3-4 cm wide; midrib impressed adaxially, prominent abaxially. Scape erect, slender, terminal, 8-20 cm high; raceme several, laxly or subdensely flowered; floral bracts ovate-lanceolate, 3.5-6 mm. Flower small, ca. $1 \mathrm{~cm}$ long, green and white. Dorsal sepal and petals connecting to form a hood, green; dorsal sepal ovate, ca. $7 \mathrm{~mm}$ long, ca. $6 \mathrm{~mm}$ wide, apex obtuse rounded; lateral sepal oblong ca. $7 \mathrm{~mm}$ long, ca. $3 \mathrm{~mm}$ wide, apex acute; Petals linear lanceolate, ca. $4.5 \mathrm{~cm}$ long, ca. $8 \mathrm{~mm}$ wide. Lip deeply 3-lobed, central lobe linear, ca. $8 \mathrm{~mm}$ long, ca. $1 \mathrm{~mm}$ wide, lateral lobes

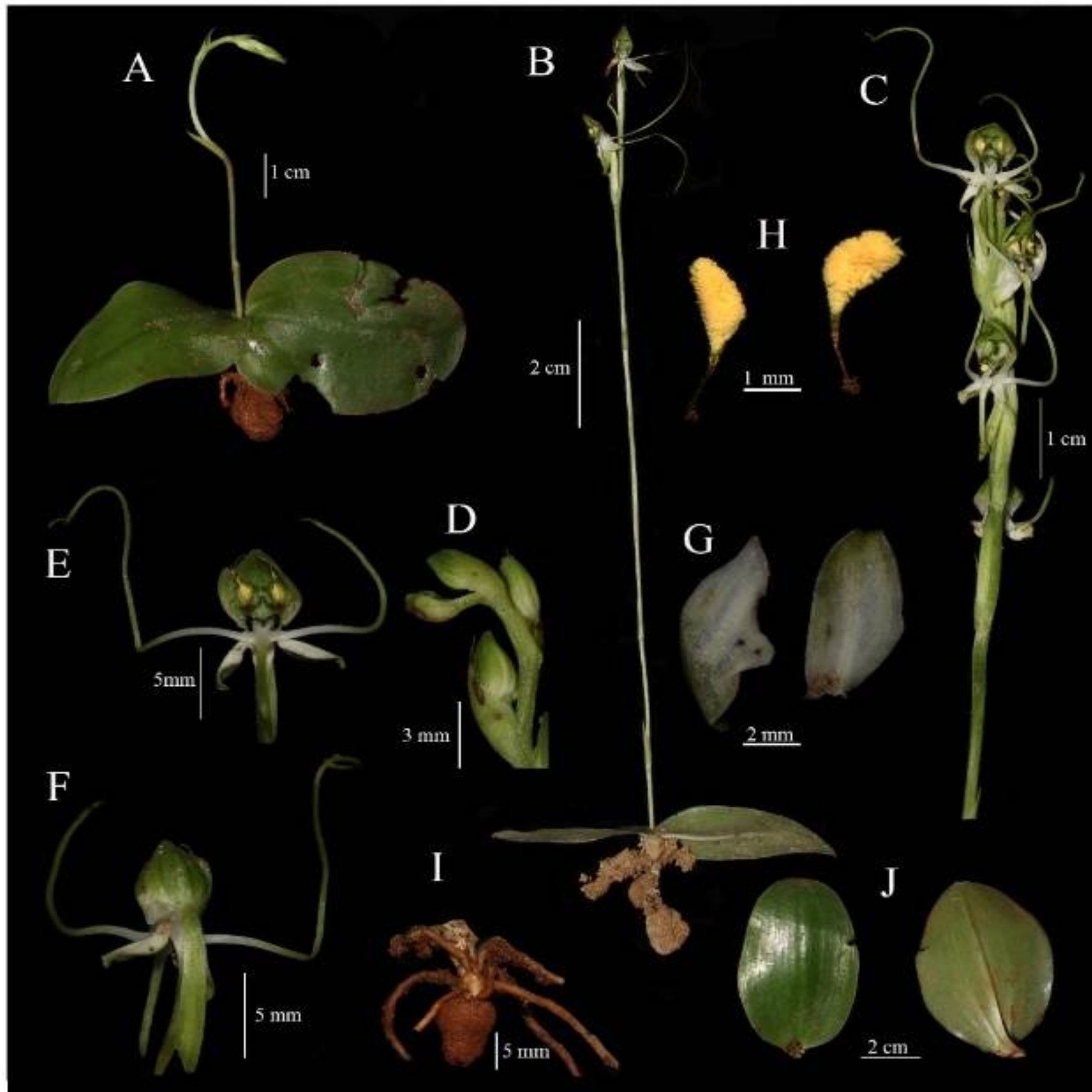

Fig. 1. Habenaria diphylla. A \& B. Details of flowering plant at young and maturity. C. Inflorescence. D. Young Flower. E \& F. Flower (front view and back view); G. Lateral sepal. H. Pollinia. I. Tuber. J. Leaves (above and below). 


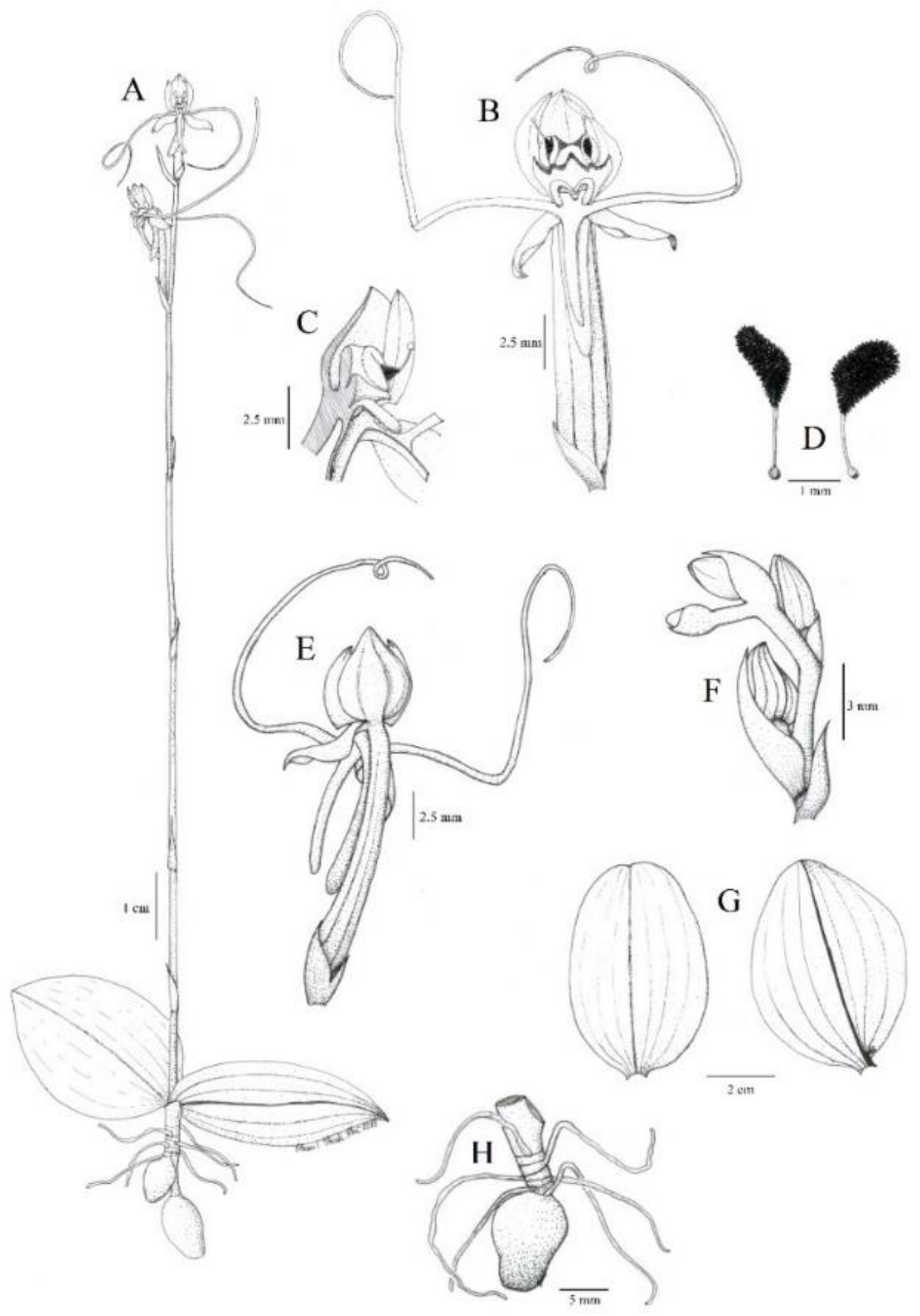

Fig. 2. Habenaria diphylla. A. Habit. B \& E. Flower (front view and back view). C. Longitudinal section of flower. D. Pollinia. F. Young Flower. G. Leaves. H. Tuber. 

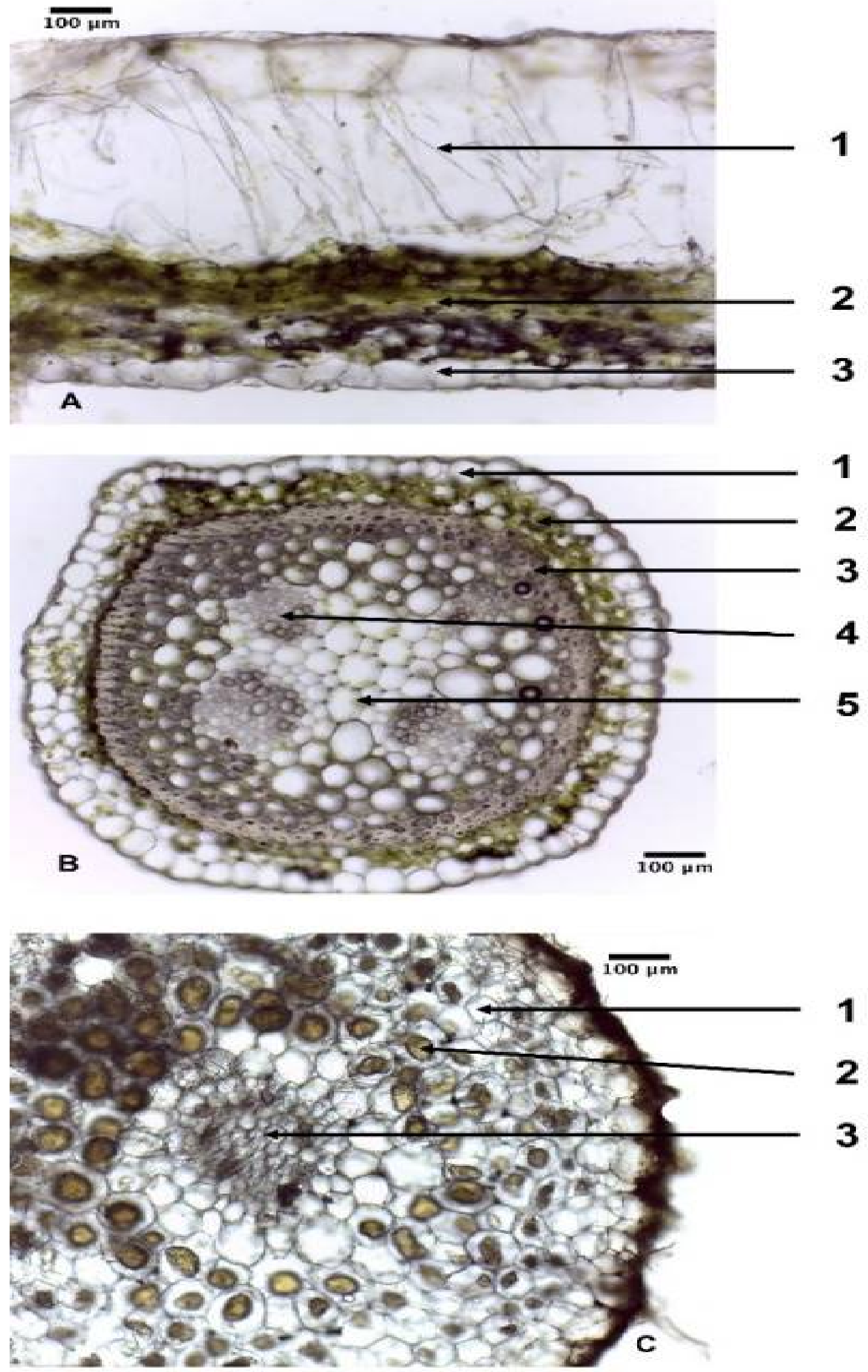

1

2

3

Fig. 3. Cross section of Habenaria diphylla. A. Leaf-1. Enlarged adaxial epidermis; 2. Mesophyll; 3. Abaxial epidermis. B. Inflorescence axis-1. Epidermis; 2. Chlorenchyma; 3. Sclerenchymatous ring; 4. Vascular bundles; 5. Parenchyma. C. Root-1, cortical parenchyma; 2. Orchid mycorrhizae; 3. Stele. 
filiform, up to $3 \mathrm{~cm}$ long, curled upward toward apex. Spur green to white, ca. $5 \mathrm{~mm}$ long, slender, curved. Pollinia 2, dark yellow, capsule fusiform.

Leaf anatomy: enlarged adaxial epidermis occupies one-half to two-thirds of leaf volume, probably function in water storage; homogeneous mesophyll. Inflorescence axis: 1 layered epidermis, ground tissues interrupts by a sclerenchymatous ring; vascular bundles are collateral; Root: orchid mycorrhizae presents in the cortical cells.

Flowering and fruiting: September to November.

Type: INDIA. s. coll. sn. (K000247479, seen image).

\section{Specimens examined}

Le Van Son 221 \& 222 (PHH), VIETNAM. Ba Ria-Vung Tau Province, Binh Chau-Phuoc Buu Nature Reserve, on $30^{\text {th }}$ August 2019 at approximate coordinates $10^{0} 30^{\prime} 38^{\prime \prime} \mathrm{N}, 107^{0} 30^{\prime} 34^{\prime \prime} E$ and $19 \mathrm{~m}$ in elevation; s. coll. sn. (K000247479, seen image), India; Dungboo. Sn (K000247481, seen image), India; Hooker JD (K000247480, seen image), India.

\section{Distribution}

Habenaria diphylla is only known from Binh ChauPhuoc Buu Nature Reserve, Bung Rieng ward, Xuyen Moc District, Ba Ria-Vung Tau Province, Vietnam.

\section{Habitat and ecology}

The species is usually found in secondary and mixed forest at wetland under forest canopy in association with such species as Cratoxylum formosum (Jacq.) Benth. \& Hook. f. ex Dyer, Eurycoma longifolia Jack, Curculigo annamitica Gagnep. and Curcuma pierreana Gagnep.

\section{Conservation status}

According to The Government of Vietnam's Decree 06/2019/ND-CP on management of endangered, precious and rare forest flora and fauna and implementation of the Convention on international trade in endangered wild animals and plants, the plant species of the Orchidaceae family are listed in group II including of the species which are not necessarily threatened with extinction, but its exploitation and trade must be controlled in order to avoid utilization incompatible with their survival (12).

\section{Authors' contributions}

This study was designed Hong Thien Van and Van Son Le are the sample collectors. The Figure 2 and 3 were performed by Thi Thanh Nha Phan and Le Anh Tuan Dang. All authors performed experiments and handled the research data. Hong Thien Van prepared the manuscript and resolved all the queries of reviewers.

\section{Conflict of interests}

No conflict of interest was declared by the authors.

\section{References}

1. Batista JA, Karina SB, Marina WF, Faria K, Aline P, Gerardo JR. Molecular phylogenetics and morphological reappraisal of the Platanthera clade (Orchidaceae: Orchidinae) prompts expansion of the generic limits of Galearis and Platanthera. Annals of Botany. 2013;104:431-45. http://doi.org/10.1093/aob/ mcp089

2. Pham HH. Orchidaceae. In: Pham-hoang H. (ed.), An Illustrated Flora of Vietnam, Youth Publishing House, Ho Chi Minh City, Vietnam. 2000

3. Nguyen TT. Orchidaceae in Vietnam, Agriculture Publishing House, Ho Chi Minh City, Vietnam, 2001.

4. Ban NT, Averyanov L, Duong DH. Orchidaceae, Checklist of plant species of Vietnam, Agriculture Publishing House, Hanoi, Vietnam, 2005.

5. Averyanov L. The orchids of Vietnam Illustrated survey part 2 subfamily Orchidoideae. Turczaninowia. 2010;13:5-98.

6. Ly NS, Tran TT, Do DG, Truong BV. Habenaria austrosinensis Tang \& F.T. Wang (Orchidaceae): A newly recorded species for Vietnam. Bioscience Discovery. 2018;9:222-26.

7. Hooker F. Flora of the Nicobar Islands, Bot. Kew Gard. Misc 1850;2:262.

8. Chen SC, Cribb JP. Habenaria Willdenow. Flora of China 2009;25:144-60

9. Kurzweil H. The genus Habenaria (Orchidaceae) in Thailand Thai Forest Bull. Bot. 2009;7:7-105.

10. Vinodia S, Dixit AK. Habenaria diphylla (Nimmo) Dalzell: A new addition to the orchid flora of Bilaspur district (Chhattisgarh), Central India. Current Botany. 2017;8:60-65 http://doi.org/10.19071/cb.2017.v8.3217

11. Bridson D, Forman L. The Herbarium Handbook. $3^{\text {rd }}$ Ed. Roya Botanic Gardens, Kew, UK, 1999.

12. The Government of Vietnam's Decree 06/2019/ND-CP on management of endangered, precious and rare forest flora and fauna and implementation of the Convention on international trade in endangered wild animals and plants. 